\title{
IMPLEMENTATION OF A RASPBERRY PI TRAINER FOR THE SUBJECT OF MICROPROCESSORS AND MICROCONTROLLERS IN VOCATIONAL HIGH SCHOOLS
}

\author{
Enjang Akhmad Juanda ${ }^{1}$, Nurul Wahidah ${ }^{2}$, M. Khairudin ${ }^{3}$, Z. Mohamed ${ }^{4}$ \\ 1,2 Department of Electrical Engineering Education, Universitas Pendidikan Indonesia, Indonesia \\ ${ }^{3}$ Department of Electrical Engineering Education, Universitas Negeri Yogyakarta, Indonesia \\ ${ }^{4}$ Faculty of Electrical Engineering, Universiti Teknologi Malaysia, Malaysia \\ E-mail: juanda@upi.edu
}

\begin{abstract}
A Raspberry Pi Trainer is a tool which is able to support and facilitate the learning process of the subject of microprocessors and microcontrollers. The objective of this study was to find out the process and the results of the implementation of a Raspberry Pi Trainer for the subject of microprocessors and microcontrollers in the expertise program of industrial electronics in vocational high schools. This study used a qualitative method. The descriptive data were resulted from the observed students' behavior in the form of the research informants' activities covering the domains of cognitive, psychomotor, and affective. There were 20 informants divided into two classes, 10 in class XII A and 10 in class XII B. Each class consisted of 2 males and 8 females. The results showed the Raspberry Pi Trainer was well applied in practical learning activities. The average abilities of class XII B and class XII A for the domains of cognitive, psychomotor and affective were categorized as very good, good and moderate respectively.
\end{abstract}

Keywords: raspberry pi trainer, practicum, learning media

\section{INTRODUCTION}

The interviews with one of the teachers in the Expertise Program of Industrial Electronics in Vocational High Schools, also known as Sekolah Menengah Kejuruan (SMK), and the author's experience in the teaching practices convinced that the graduate candidates in Vocational High Schools should have good skills and should be innovative and creative in accordance with the mission of Vocational High Schools to compete in the world of work. The skills required include maintenance and repair skills or maintenance and troubleshooting. Ministry of Labour (2006) in Martono \& Wagiran (2016) states that a training module is a description of the training materials prepared based on standards of competence using competency-based training as an approach to acquire the appropriate skills in the workplace.

Learning media is required to effectively deliver the materials taught by teachers. Zuhrie et al. (2017) suggest that learning media should
One of learning media that meet the students' needs. commonly used is a trainer set to be used as a practicum tool. This study applied microcontrollers programming materials for control equipment that suits the needs of the industry. Learning media in this study was used to add new knowledge about Raspberry Pi and Python programming languages. Raspberry Pi can be defined as a minicomputer that functions more than just an embedded computer but it can also be used in the world of education to introduce computer science and programming to the students in a simpler way.

Sukmawan (2013) studied the implementation of a portable analog or digital training module as a learning media of a microcontrollers system in terms of students' learning outcomes on the competency standard of learning ADC input or output, PWM, Interrupt and Motor Stepper in SMK 2 Cimahi. $\mathrm{He}$ used the method of research and development ( R \& D) that emphasized more on cognitive domain assessment (Aning, 2013). In 
the other hand, this study used the research method of descriptive qualitative that emphasize more on individual assessments.

The design of the Raspberry Pi trainers in this study consists of two-parts, hardware and software. The specifications are (1) the sensor used is DHT22, (2) the lamp used is LED, and (3) the Raspberry Pi used is Raspberry Pi 3 B type with the specification of $1.2 \mathrm{GHz}$ 64-bit quad-core ARMv8 CPU, 802.11n Wireless LAN, Bluetooth 4.1, Bluetooth Low Energy (BLE), 1GB RAM, 4 USB ports, 40 GPIO pins, Full HDMI port, Ethernet port, Combined $3.5 \mathrm{~mm}$ audio jack and composite video, Camera interface (CSI), Display interface (DSI), Micro SD card slot (now push-pull rather than pushpush), and VideoCore. The system works effectively and support the experiment. This study was conducted using a qualitative research approach in the aspects of cognitive, affective and psychomotor with its limitations used for each subdomain.

\section{METHOD}

This study is a qualitative study which is aimed for exploring and understanding the meaning (a number of individuals or groups of people) that are deemed to come from social or humanitarian issues including important efforts, such as asking questions and procedures, collecting specific data from the subjects, analyzing data inductively from specific themes to common themes, and interpret the meaning of data (Creswell, 2013). A qualitative method is a research procedure where the final data results are descriptive data, in the form of written or oral words of the person or behavior being observed (Bogdan, 1975). Thus qualitative research is a method used to explore and understand the individual on the problem that produces descriptive data to gain insight into the interesting phenomenon.

Research informants are sources of data to collect information in accordance with the research questions. The study was conducted to examine the impact of the implementation of a Raspberry Pi Trainer as learning media for the subject of Microprocessors and Microcontrollers in the Expertise Program of Industrial Electronics in Vocational High Schools in Bandung, West Java. The informants consists of 20 students from class XII A and class XII B. The consideration in determining the number of informants is each research informant in a relatively short time should be able to provide adequate information (Moleong, 2014). The qualitative design has a flexible nature so that in the sample selection there are no definite rules to be taken for qualitative research (Patton, 2002).

The object of a study is based on social situations being studied. The social situation in this study is the activity of the students in the use of a Raspberry Pi Trainer as learning media for the subject of Microprocessors and Microcontrollers in the Expertise Program of Industrial Electronics at Vocational High Schools in Bandung, West Java for the aspects of cognitive, affective and psychomotor. Figure 1 shows a picture of the raspberry pi trainer trainer set and the jobsheet.

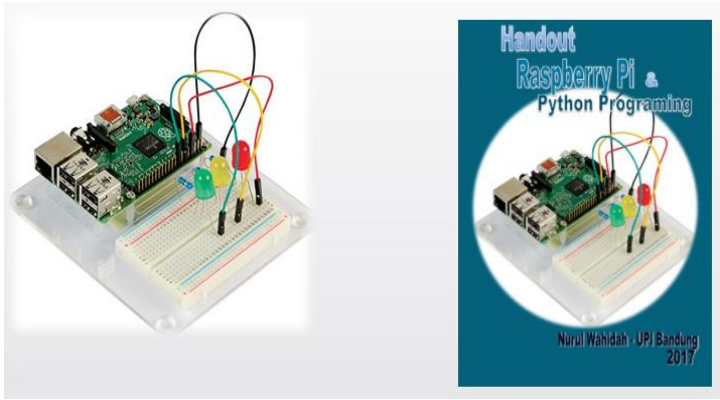

Figure. 1 Raspberry Pi Trainer Set and the Jobsheet

There are criteria that must be observed for each category to facilitate the data processing from the observation. The assessments were performed by using measurement scales based on the 2013 curriculum with four scales for the affective domain. The rating scales consist of very poor, poor, enough, and good. The cognitive and psychomotor domains have four scales using numerical scoring from 1 to 4 . The results of this gradient will result in a score of 0 to 100 
(Directorate of Vocational Education, 2016). Furthermore, the research procedure is presented in Figure 2.

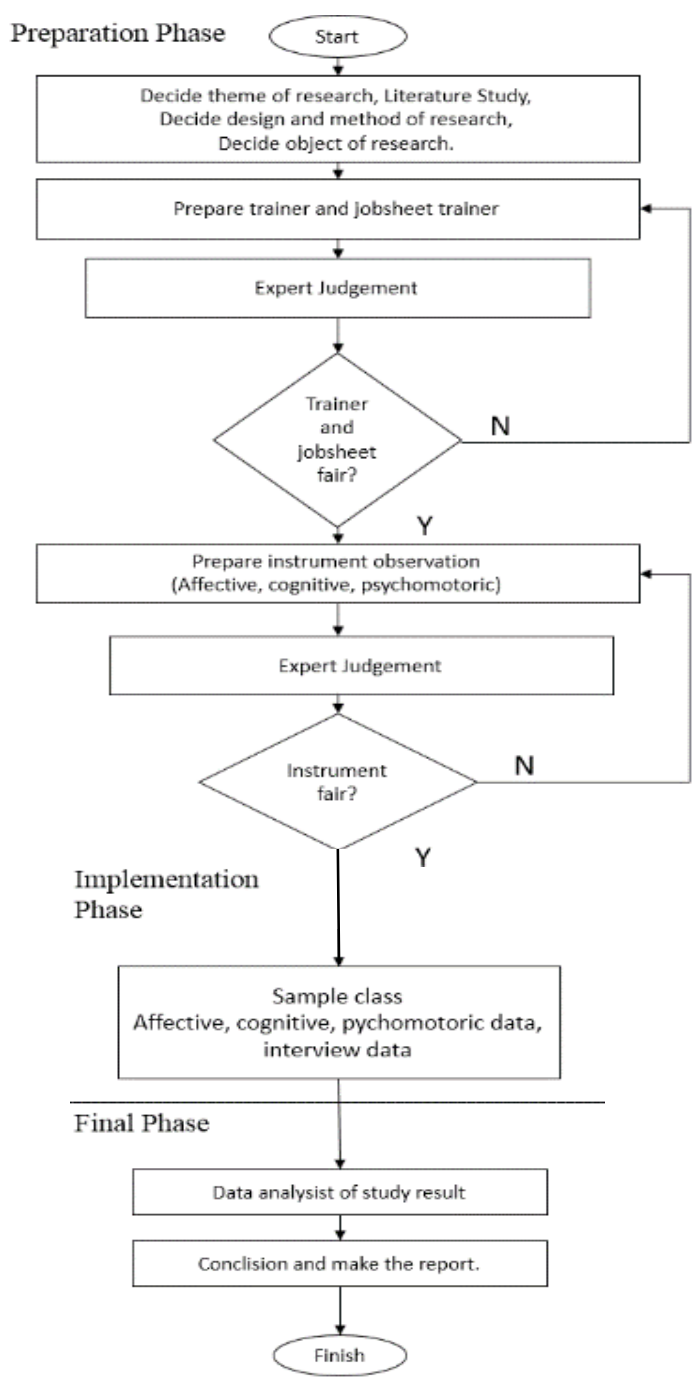

The preparation before conducting the study consisted of (a) initial observation to carry out a preliminary study through an observation of the learning process in the aspects of learning condition, learning methods, and instructional media (b) literature studies to obtain relevant theories to be the basis of the problems of the study, (c) curriculum analysis to determine the learning materials and the basic learning goals and competencies to be achieved, (d) selection of the research sample, (e) preparation of the instruments grid, lesson plans, practical worksheets and instruments for cognitive, affective and psychomotor observation, (f) expert judgment of the research instruments.
The implementation stage included (a) Implementation of the Raspberry Pi Trainer as a learning media in the practical learning, (b) providing questions to know the learning results in the cognitive domain, (c) observation in the affective and the psychomotor domains, through the attitude of each informant during the practical learning.

After the implementation stage, data processing and analysis were performed. The data processing describes techniques and steps taken in processing or analyzing the data. The qualitative data were analyzed using the analysis technique by Miles \& Huberman (1984) that consisted of (a) collecting research data, selecting the main points, focusing on the important things in accordance with the objectives of the study and summarizing the analysis results of the temporary data, (b) conducting interviews to complete the necessary data, (c) obtaining from observations and interviews, (d) performing data presentation with narrative texts, (e) making conclusion and verification. Initial drawing conclusions are temporary and must be verified with other data from interviews and field notes.

There were several data collections techniques used in this study that consisted of observations, interviews, and documentation. A qualitative observation is an observation where the researchers go directly to the field to observe the behavior and individual activities in the research location (Patton, 2002). In this observation, the researcher records either in a structured or semistructured (e.g. by asking a number of questions that the researcher wants to know). In qualitative manner, the researchers are also involved in various roles, ranging from non-informants to intact informants (Creswell, 2013). Observation is a common way to gain confidence in the validity of data, because with observation the researchers will observe and experience the event directly (Moleong, 2014). In this study, observations were conducted to observe the phenomenon that occurs when the Raspberry Pi Trainer was applied. This 
observation included the aspects of the students' affective, cognitive and psychomotor.

In qualitative interviews, the researchers interviewed the informants through face-to-face interviews, phones, or specific group interviews consisting of 6 to 8 group informants. An interview generally requires unstructured and open-ended questions designed to elicit opinions from the informant (Creswell, 2013). The interview conducted were open and written, to obtain information that can strengthen the results of observation and dig more information. Interviews were conducted when the informant was observed by the researcher. The interview covered the questions related to the understanding, the features, the work principles, the troubleshooting of the Raspberry Pi Trainer, the experience in using the Raspberyy Pi trainer and other media in addition to the Raspberry $\mathrm{Pi}$ Trainer.Futhermore, the documentation used was in the form of photos and sound recordings. The documentation can be used to check the from observations and interviews (Creswell, 2013).

In qualitative research, data analysis involves the collection of open power, based on general statements, and information analysis from the informant (Creswell, 2013). The data analysis technique used in this research was the model by Miles \& Huberman (1984). The data analysis was performed interactively, thoroughly, and continuously thus the data is saturated (Denzin, 2009). It consisted of three interrelated sub processes namely, data reduction, data presentation and conclusion or verification.

The triangulation method is conducted for conclusion and verification. The data collection techniques are a combination of various data collection techniques and data sources. The data are collected and tested for its credibility with various techniques of data collection and various data sources (Sugiyono, 2014). In addition, triangulation of techniques was used by applying different data collection techniques to get data from the same source. While the triangulation of sources obtains data from different sources with the same technique (Sugiyono, 2014).

In the final step, the conclusions were drawn with the interpretation to find the meaning of presented data. The data that were analyzed, explained and interpreted in the form of words to describe the facts in the field, meaning or to answer research questions were then selected to get the essentials.

\section{RESULTS AND DISCUSSION}

The level of the students' achievement in Class XXI A for the domains of affective, psychomotor and cognitive is presented in Table 1.

Table 1. The Overall Record of Class XII A

\begin{tabular}{|c|c|c|c|c|}
\hline \multicolumn{2}{|c|}{ Criteria for the Domain } & Total & $\begin{array}{l}\text { Final } \\
\text { Score }\end{array}$ & $\overline{\text { Average }}$ \\
\hline \multirow{4}{*}{ Affective } & $\begin{array}{l}\text { Receive } \\
\text { (A1) }\end{array}$ & 40 & 100 & \multirow[t]{4}{*}{86.87} \\
\hline & $\begin{array}{l}\text { Response } \\
\text { (A2) }\end{array}$ & 30 & 75 & \\
\hline & $\begin{array}{l}\text { Appreciate } \\
\text { (A3) }\end{array}$ & 31 & 77.5 & \\
\hline & $\begin{array}{l}\text { Living } \\
\text { (A4) }\end{array}$ & 38 & 95 & \\
\hline \multirow{3}{*}{ Psychomotor } & $\begin{array}{l}\text { Proficient } \\
\text { (P3) }\end{array}$ & 39.49 & 98.725 & \multirow[t]{3}{*}{83.74} \\
\hline & $\begin{array}{l}\text { Natural } \\
\text { (P4) }\end{array}$ & 31 & 77.5 & \\
\hline & $\begin{array}{l}\text { Original } \\
\text { (P5) }\end{array}$ & 30 & 75 & \\
\hline \multirow{4}{*}{ Cognitive } & $\begin{array}{l}\text { Understanding } \\
\text { (C2) }\end{array}$ & 31.25 & 78.125 & \multirow[t]{4}{*}{71} \\
\hline & $\begin{array}{l}\text { Apply } \\
\text { (C3) }\end{array}$ & 22.35 & 55.875 & \\
\hline & $\begin{array}{l}\text { Analyze } \\
\text { (C4) }\end{array}$ & 30 & 75 & \\
\hline & $\begin{array}{l}\text { Evaluate } \\
\text { (C5) }\end{array}$ & 30 & 75 & \\
\hline
\end{tabular}

The averages obtained from each domain criteria in the aspects of affective, psychomotor cognitive were categorized as very good and moderate respectively. The average results of the assessment from 10 informants in Class XII B were categorized as good for the aspects of affective, cognitive and psychomotor. However, there were few informants whose scores were categorized as poor. Informants 2, 4, 5, 6, and 9 were categorized as good. The informants were able to use the trainer with good skills and only 
found few difficulties in the practical learning. They were skilled in using the Raspberry Pi Trainer and were able to analyze the laboratory results. The five informants had similar skills because they shared knowledge when there was something they did not know and often asked the tutor to help.

The middle category can be determined as to Informants $1,3,7,8$, and 10 had difficulty in the practical learning. Five informants mastered Web server configurationwell and were skilled in pushbutton input programming and LED output even they initiatively tried other programs with their own creativity. There as no informants with low category because all informants were active in using an mastering the Raspberry Pi Trainer. The level of the students' achievement in Class XXI B for the domains of affective, psychomotor and cognitive is presented in Table 2.

Table 2 Overall Record of Class XII B

\begin{tabular}{rlccc}
\hline Criteria for the Domain & Total & $\begin{array}{l}\text { Final } \\
\text { Score }\end{array}$ & Average \\
\hline $\begin{array}{l}\text { Receive } \\
\text { (A1) }\end{array}$ & 40 & 100 & 88.125 \\
$\begin{array}{l}\text { Response } \\
\text { (A2) }\end{array}$ & 30 & 75 & \\
Psychomotiver & $\begin{array}{l}\text { Appreciate } \\
\text { (A3) }\end{array}$ & 35 & 87.5 & \\
$\begin{array}{l}\text { Living } \\
\text { (P4) }\end{array}$ & 36 & 90 & \\
$\begin{array}{l}\text { (A) } \\
\text { Original } \\
\text { (P3) }\end{array}$ & 38.66 & 96.65 & 83.05 \\
$\begin{array}{l}\text { (P5) } \\
\text { Understanding } \\
\text { (C2) }\end{array}$ & 34.25 & 85.625 & 79.219 \\
$\begin{array}{l}\text { Apply } \\
\text { (C3) }\end{array}$ & 31 & 77.5 & \\
Cognitive & 30 & 75 & \\
$\begin{array}{l}\text { Analyze } \\
\text { (C4) }\end{array}$ & 31.5 & 78.75 & \\
$\begin{array}{l}\text { Evaluate } \\
\text { (C5) }\end{array}$ & 30 & 75 & \\
\hline & & & \\
\hline
\end{tabular}

The averages obtained from each domain criteria in the aspects of affective, psychomotor cognitive were categorized as very good, skilled and good respectively. Of 20 informants with the lowest scores, there were 5 informants from class XII A who had less scores namely Informants 1, 2, 4, 6, and 7. The results of the interviews showed that the five informants were not able to use the Raspberry pi tainer during the practical learning.

Informant 1 got the problem with his laptop to connect to the internet so he was left behind. In addition, the informants did not read the handouts carefully. Informant 1 found difficulties in the programming language and was still confused to find the IP address of Raspberry pi. Informant 1 had high motivation to better learn the Raspberry Pi trainer.

Informant 2 found difficulties in pushbutton input practices and LED output because he did not undertand how to determine GPIO pin to be used and he often saw the datasheet of GPIO pin. At the interview, the informant showed the motivation to learn more about the Raspberry Pi.

Informant 4 hardly explained the steps to operate the Raspberry Pi Trainer. The informant did not answer the tutor's question about the work process of the Raspberry Pi Trainer because he often chatted with his friend, did not pay attention to the tutor, never asked the tutor about his difficulties and often went out of the class.

Informants 6 and 7 had the same difficulty $\mathrm{n}$ reading the handouts. Both informants were able to explain the Raspberry pi features smoothly, but in practices, they found the difficulty in finding the GPIO pin to be used. Informant 6 tried to pin GPIO which is not suggested by the tutor but he could run it well, whereas Informant 7 had a problem when running the LED program with difficulties in the determined circuit. At the interview, they showed their motivation to learn the Raspberry Pi trainer. The following data presented in Table 3 was obtained from the observations including the domains of affective, cognitive, and psychomotor. 
Table. 3 Description of First Informant

\begin{tabular}{|c|c|c|c|}
\hline \multirow{3}{*}{ Aspect } & \multicolumn{2}{|c|}{ Data } & \multirow{3}{*}{ Explanation } \\
\hline & \multicolumn{2}{|c|}{ Retrieval } & \\
\hline & 1 & 2 & \\
\hline Accept & - & $\mathrm{VG}$ & $\begin{array}{l}\text { All indicators of the assessment of discipline showed that for this aspect, } \\
\text { the informants' scores are categorized as very good. }\end{array}$ \\
\hline Responding & & & $\begin{array}{l}\text { The assessment of responsibility showed the informants' scores are } \\
\text { categorized as good. }\end{array}$ \\
\hline Appreciate & & & $\begin{array}{l}\text { The assessment of cooperation showed the informants' scores are } \\
\text { categorized as very good. }\end{array}$ \\
\hline Inspire & & & $\begin{array}{l}\text { The assessment of courtesy showed the informants' scores are categorized } \\
\text { as very good. }\end{array}$ \\
\hline Practicing & & & $\begin{array}{l}\text { The assessment of confidence showed the informants' scores are } \\
\text { categorized as very good. }\end{array}$ \\
\hline Proficient & 80.5 & 83.3 & $\begin{array}{l}\text { Informants can meet all of the criteria. the informants' level are } \\
\text { categorized as highly skilled. }\end{array}$ \\
\hline Natural & & & $\begin{array}{l}\text { Informants can meet several criteria, but they hardly collect the data source } \\
\text { that will be used to do programming. The informants' level is categorized } \\
\text { as moderate. }\end{array}$ \\
\hline Original & & & $\begin{array}{l}\text { Informants can meet several criteria, they can do a test and simulate the } \\
\text { data input and output. The informants' level is categorized as skilled. }\end{array}$ \\
\hline Understand & 80.9 & 68.3 & $\begin{array}{l}\text { Informants can answer some questions properly, but still struggle to } \\
\text { explain the steps in the operating system, setting the internet and IP } \\
\text { address using the remote desktop connection. The informants' level is } \\
\text { categorized as moderate }\end{array}$ \\
\hline Apply & & & $\begin{array}{l}\text { Informants can answer some questions properly but they feel difficulties in } \\
\text { the configuration of the Raspberry as a web server. The informants' level } \\
\text { is categorized as moderate }\end{array}$ \\
\hline Analyze & & & $\begin{array}{l}\text { Informants can program the series with the right, but they have trouble for } \\
\text { the pushbutton in importing library GPIO. The informants' level is } \\
\text { categorized as moderate }\end{array}$ \\
\hline Evaluate & & & $\begin{array}{l}\text { Informants can check the programs that have been made properly, but in } \\
\text { uploading to the trainer they had difficulties. The informants' level is } \\
\text { categorized as moderate }\end{array}$ \\
\hline
\end{tabular}

Where VG $=$ Very Good

The first informant's psychomotor had increased that was indicated by the observation in the laboratory work. In the laboratory work she had difficulties in the actual simulation program and test, but in the laboratory work both of informants were able to do well because the informants already started to get used to the Raspberry Pi programming. Informant 1 was able to meet all the criteria in the affective. The cognitive aspect of the informants 1 was poor because during the pratical learning, the informant did not pay attention to the instructor's explanation.
The data of the interview from 20 informants based on the topics are presented in Table 4. Table 4 indicates that the informants could explain the sense, the features and the work process of the Rasberry $\mathrm{Pi}$ trainer, although there was one informant who was unable to answer the question,looked confused in responding and did not understand the delivered materials. The informants were not familiar with the materials of the Raspberry Pi Trainer that were never studied before, thus they found difficulties in the laboratory work 
Table 4. The Interview Results

\begin{tabular}{|c|c|c|}
\hline No. & Topic & Conclusion \\
\hline \multirow[t]{7}{*}{1.} & \multirow{7}{*}{$\begin{array}{l}\text { Understanding } \\
\text { the Raspberry } \\
\text { Pi Trainer }\end{array}$} & Raspberry Pi Trainer is a mini \\
\hline & & computer \\
\hline & & microcontrollers with its \\
\hline & & features and functions. \\
\hline & & Informants can answer all \\
\hline & & related to a \\
\hline & & $\begin{array}{l}\text { Raspberry } \mathrm{Pi} \text { Trainer, in } \\
\text { accordance with their own } \\
\text { opinion. }\end{array}$ \\
\hline \multirow[t]{8}{*}{2.} & Features & The features of a Raspberry $\mathrm{Pi}$ \\
\hline & Raspberry Pi & Trainer include USB, GPIO, \\
\hline & Trainer & $\begin{array}{l}\text { LAN, HDMI, Camera, Sound, } \\
\text { and others. The application in }\end{array}$ \\
\hline & & everyday life is as \\
\hline & & microcontrollers. Informants \\
\hline & & can answer all questions \\
\hline & & related to a Raspberry $\mathrm{Pi}$ \\
\hline & & $\begin{array}{l}\text { Trainer, in accordance with } \\
\text { their own opinion. }\end{array}$ \\
\hline \multirow[t]{7}{*}{3.} & \multirow{7}{*}{$\begin{array}{l}\text { Work process } \\
\text { Raspberry Pi } \\
\text { Trainer }\end{array}$} & Work process of Raspberry Pi \\
\hline & & Trainer starts from the rise of \\
\hline & & $\begin{array}{l}\text { the raspberry on the remote } \\
\text { desktop connection, installing }\end{array}$ \\
\hline & & apache, PHP, MySQL, \\
\hline & & programmed LED and \\
\hline & & $\begin{array}{l}\text { Pushbutton. Informants had } \\
\text { four difficulties to answer this }\end{array}$ \\
\hline & & $\begin{array}{l}\text { topic because Informants } 4 \\
\text { can receive the materials } \\
\text { submitted by the instructor, } \\
\text { while the other give true } \\
\text { answers although the answers } \\
\text { are not complete }\end{array}$ \\
\hline \multirow[t]{5}{*}{4.} & Benefit & The Raspberry Pi Trainer is \\
\hline & Raspbery Pi & used to add insight and \\
\hline & Trainer & knowledge of the Raspberry \\
\hline & & Pi. Informant 4 have not been \\
\hline & & $\begin{array}{l}\text { able to mention the benefits of } \\
\text { Raspberry Pi Trainer. }\end{array}$ \\
\hline \multirow[t]{3}{*}{5.} & Problem & The problem of Raspberry $\mathrm{Pi}$ \\
\hline & Raspberry Pi & Trainer, is that the Raspberry \\
\hline & Trainer & $\begin{array}{l}\text { Pi Trainer is new for the } \\
\text { informants so that it takes a } \\
\text { long time to learn it, At the } \\
\text { second meeting, they are more } \\
\text { able to use the trainer. }\end{array}$ \\
\hline \multirow[t]{4}{*}{6.} & Learning & In addition to the Raspberry $\mathrm{Pi}$ \\
\hline & Media beside & Trainers, the informants \\
\hline & Raspberry Pi & Learning media the Informants \\
\hline & Trainer & $\begin{array}{l}\text { use is ATMEGA. They have } \\
\text { understood well. }\end{array}$ \\
\hline \multirow[t]{3}{*}{7.} & Experiences & Experience of using Raspberry \\
\hline & use Raspberry & Pi Trainer, the Informants felt \\
\hline & Pi Trainer & $\begin{array}{l}\text { motivated to learn more about } \\
\text { the trainer. }\end{array}$ \\
\hline
\end{tabular}

Note: $\mathrm{VG}=$ Very Good
In the implementation process of the Raspberry Pi Trainer as Learning Media Informants 1 and 7 experienced difficulties in simulating and testing the program, but in the laboratory work both of them were able to do well because the Informants already got used to the Raspberry Pi programming. The informants 2 and 6 had difficulty in filling the OS Raspbian in the Raspberry Pi Trainer, but in the laboratory work, both of them were also able to do well because they already started to get used to the Raspberry Pi programming. Informants 4 and 10 had problems in doing data processing input and output of the trainer, but in the laboratory work, both of informants were able to do well because the informants already got used to the Raspberry Pi programming.

Informants 5 and 9 had difficulties in performing the process of the trainer programming, but in the laboratory work both Informants were able to do well because of the Informants already started to get used to the Raspberry Pi programming. Informants 3 had difficulties in finding the IP address from the Raspberry pi to enter PuTTY, but in the laboratory work, both informants were able to do well because the Informants already started to get used to the Raspberry Pi programming. Informants 8 had difficulties in determining the software to be used in the Raspberry Pi Trainer, but in the laboratory work the informant was able to do well because the informant already started to get used to the Raspberry $\mathrm{Pi}$ programming.

It was concluded that the Raspberry $\mathrm{Pi}$ Trainer was able to provide many experiences so that it provided ease in the training and assess each individual. Informants also found difficulties in using the Raspberry Pi Trainer because the time allocation to study the Raspberry Pi Trainer is only one minute, while to learn the materials of the Raspberry $\mathrm{Pi}$ Trainer actually needs longer time. 
All Informants had very good scores for their affective aspect, except for Informant 8 who had poor attitude because the Informant did not carry out the duties appropriately. Informants 4 and 10 had higher scores on the psycomotor aspect compared to the others. This was because they were active in completing any jobsheets. If they did mistakes or errors they solved them immediately. In the other hand, female students tended to get panicked when there were errors and hardly solved the errors.

Informants 8, 9 and 10 had not too different scores, i.e 70 in a 100 scale. The others got the scores under 70. This is because the Raspberry Pi Trainer is still new for them. In conclusion, the average capability in class XII for the domains of affective, psycomotoric and cognitive were categorized as very good, good, and moderate respectively. Each individu received an opportunity for getting the same experience in learning but produces different results.

\section{CONCLUSION}

The Raspberry Pi Trainer Set was effectively applied as the learning media to enhance learning outcomes in the subject of Microprocessors Ana Microcontrollers. Informants involved in this study had various levels of abilities and achievement, between gender and between person to person. The actual, especially present condition of the students will be influenced by learning process, not merely by the IQ factor. The results showed the Raspberry Pi Trainer was well applied in practical learning activities. The average abilities of the students for the domains of cognitive, psychomotor and affective were categorized as very good, good and moderate respectively.

\section{REFERENCES}

Aning. 2013. Penerapan Modul Latih Portable Analog/ Digital sebagai Media Pembelajaran Sistem Mikrokontroler.
Bandung: Universitas Pendidikan Indonesia.

Bogdan. 1975. Introduction to Qualitative Research Methods. New York: John Willey and Sons

Creswell. 2013. Research Design Pendekatan Kualitaif, Kuantitaif, dan Mixed (B. B. A. Achmad Fawaid, Saifuddin Zuhri Qudsy, Haitamy El Jaid Ed.)(3rd Ed). Yogyakarta: Pustaka Pelajar

Denzin. 2009. Handbook Of Qualitative Research. (S. Z. Qudsy, Ed.) (1st ed.). Yogyakarta: Pustaka Pelajar

Directorate of Vocational Education. 2016. Pelatihan Implementasi Kurikulum 2013 Sekolah Menengah Kejuruan. Jakarta: Ministry of Education and Culture of Indonesia

Martono \& Wagiran. 2016. Developing a Learning Module for Computer Numerically Control GSK 983 Machines to Enhance Students' Learning Outcomes. Jurnal Pendidikan Teknologi dan Kejuruan. 23. 2, 185

Moleong. 2014. Metodologi Penelitian Kualitatif Edisi Revisi. Bandung: PT Remaja Rosda Karya

Patton. 2002. Qualitative Research \& Evaluation Methods. California: Sage Publication

Sugiyono. 2014. Metode Penelitian Pendidikan. Bandung: Alfabeta

Zuhrie, M. S, Basuki, I. \& Asto B, I. G. P., Anifah, L. Design of an Artificial Intelligence Robot as a Tool for Teaching Media Based On Contextual Teaching and Learning. Jurnal Pendidikan Teknologi dan Kejuruan. 23. 4, 369-373 